\title{
Research on the Strategy of Integrated Development of the Urban and Rural Road Passenger Transport --Take Guiyang As an Example
}

\author{
Linghong Wei \\ China Urban Sustainable Transport Research Center(CUSTReC), Beijing, 100029, China \\ weilinghong@163.com
}

\begin{abstract}
Keywords: Research; Urban and Rural Passenger Transport; Integrated; Strategy.
Abstract. Since the 16th CPC National Congress, Integrated and coordinated urban and rural development into national strategies. Integration of urban and rural road passenger transport is an important support for the development of urban and rural integration, Promote integrative construction of urban and rural road passenger transport is to strengthen rural infrastructure and important component of the public service system construction. In recent years, GuiYang accelerating urban and rural road passenger transportation, Continuously improve service quality, in order to meet urban and rural road passenger transport demand. First, this paper analysis of development status of integrated urban and rural road passenger transportation in GuiYang, Then, in-depth analysis of causes of problems, and study domestic urban cases. Finally, paper proposes measures. This paper provides a theoretical foundation and technical support integrated development of urban and rural road passenger transport for Guiyang.
\end{abstract}

\section{Introduction}

Integration of urban and rural road passenger transport is through the rational allocation of elements of urban and rural road passenger transport, construction and operation station structure, vehicle, extended network and management system combine to become one to achieve the orderly flow of visitors and the orderly operation of the market, and ultimately achieving purpose of passenger travel, promoting social and economic development.

Promoting the integrated development of urban and rural road passenger transport, is an important measure to implement the central strategy of coordinated development of urban and rural, is to accelerate the transformation of the urban and rural road passenger transport development, improvement of business skills, develop a comparative advantage, there is an urgent need for sustainable development, to promote the equalization of basic public services in urban and rural road passenger transport is important. In recent years, GuiYang, under the support of Governments, Combined actively promote the integration of urban and rural road passenger transport development with their actual.

\section{Integrated development of urban and rural road passenger transport situation}

In recent years, the urban and rural road passenger service levels improved significantly, historic changes in the appearance of road transport. However, due to the reform shorter, many problems left[1-3].

(1)The establishment of a new system traffic and transportation industry management integration

First, the formulation of relevant policies and regulations issued, government encourages the public, control bus contract, prohibition of affiliated business policy oriented, clear line right to due legal effects and different road passenger service area, and so on. Second, is the overall planning function: development of the urban and rural road passenger transport development planning as well as network and station planning. Third, strictly in accordance with the general plans and specific planning requirements for the implementation of administrative licensing, ensuring road passenger service capacity development balanced with clear service boundaries. Fourth in service-defined under classified supervision for public welfare services and competitive services to ensure quality of 
service and security. Fifth is to strengthen the administrative supervision of the urban and rural road passenger transport market.

(2)The establishment of urban and rural road passenger transport market entry and exit mechanisms

First, strengthening the macro-control and adjustment of transportation structure. In terms of capacity is mainly to encourage and guide enterprises selected for transport of light weight, high load, low energy consumption and environment-friendly, economical vehicle, in respect of transport management structure, to increase the proportion of direct passenger transport in urban and rural passenger transport industry quickly. Second, strict market access, improve the entry threshold. To regulate behavior, clear-approval standards, standardizing approval procedures, in accordance with the principle of line, establishment of administrative examination and approval system of accountability. Rural and urban areas should receive better access conditions and standards in the field of road passenger transport.

(3)Enhance the level of service management

Improving the environment, improving passenger waiting comfort; based on actual Guiyang, open custom bus, green transportation, community bus service, bus services to diversify the products in Guiyang. Strengthening the transportation emergency response information system. For possible emergency events such as natural disasters, public safety and health, continue to improve the corresponding special contingency plans; Clear transport duties at different levels, strengthening the transportation emergency response information system, form municipal, county and township, three-level traffic emergency dispatching system, information exchange and sharing to achieve at all levels of command and dispatch Center, Improving emergency response and command and dispatch capabilities.

(4)Establishing urban and rural road passenger transport financial supporting policy system

Rational definition of operating cost, annual assessment of the implementation, normative subsidy mechanism, and gradually establish a cost regulation system. Policy exempt from building infrastructure facilities for urban and rural public stations, green spaces occupy compensation fees, and public transit hub station, interchange station, dock shelters, point, car parks and other station construction in urban and rural planning and budget priorities to protect it. Retrofit passenger bus lines, can enjoy equal treatment for urban public transport; operational difficulties of rural passenger lines can be performed with reference to the transformation of the bus line.

\section{Typical Cases}

Liyang city which in Jiangsu Province.

Since 2005,Liyang took the lead in starting "The project of integrative public transit in urban and rural areas", standardization of all towns in the city built rural passenger transport station and realize its online booking, bus shelter built 580, downtown to all towns are put in a new air-conditioned buses, and gradually formed a "city, town and village" trinity new patterns of urban and rural bus transportation. Actively explore the new mode "1 yuan system" of town and village bus, the main business district municipalities establish public transportation[4].

Liyang to strengthen the management of public municipalities, towns and villages set up a bus company, responsible for daily management of municipalities transit vehicles purchased by the company group, selected in line with the requirements of rural roads open to minibus, spraying eye-catching signs logo, telephone supervision, the docking site and so on.

All lines to implement public, the conductor of the bus, the whole fare 1 yuan, buses run approximately every ten minutes or so intervals, each line total more than 40 trips per day, fully meet the travel needs of the villagers.

Jiaxing city which in Zhejiang Province

First, regional management regimes. Level areas can be divided into five areas, consists of three of the company's franchise, operating subject to overall arrangement of routes and vehicles in the region, and mastery of the villages within the zone is responsible for providing bus services. By area 
operations, the villages bus access rate responsibility system to solve the "hotline" overheating," old line" cold conflicts. Second, professional management. Jiaxing developed the Standard for bus service, requiring the company to develop management systems, operation and service standards. Third in the cost accounting based on the integration of urban and rural bus fares policy. Average basic tariff on passenger cars mileage 0.12 yuan per person, air conditioned passenger freight mileage 0.16 yuan per person, charging according to the stations. Four,in coordination with the public security departments to determine the standard of urban and rural public transport vehicle occupant.Referring to the standard buses is determined to increase the vehicle stations, and to consider the difference between urban roads and highways on the technical design, the provisions of Jiaxing city's buses by $0.125 \mathrm{~m} 2 /$ person approved, urban and rural buses by $0.15 \mathrm{~m} 2 /$ authorized person, better solve the problem of insufficient capacity passenger flow peak[4].

\section{Guiyang urban and rural road passenger transport integrated development Countermeasure}

(1)Inadequate capacity of urban and rural road passenger transport infrastructure services

One is the station's overall construction and urban planning and development coordination. Mainly to the station layout and population distribution, industrial distribution space structural changes are not synchronized, the station features different step type and capacity and passenger demand. Second, station construction is relatively lagging behind road network construction. The total lack of urban and rural passenger station, technical level be improved. Third, the lack of passenger transit hub station of the cohesive function of urban and rural areas. Public transport interchanges and bus terminal does not converge, accomplishment of a passenger station transfer. Fourth is the unbalanced development of stations. Below the county level (rural) passenger station development is relatively slow.

(2)Urban and rural road passenger service area boundaries blur

Various urban and rural road passenger service area boundaries blurred, fringe and other sensitive areas of road passenger transportation service business property is not clear, urban public transport extension and short-distance passenger service areas cross class lines; the main city and the surrounding county towns, there are counties district and rural passenger bus lines and overlapping. This problem is universal across the country, meanwhile with local characteristics of urban development strategy shift.

(3) Line management contracting operation mode is not standard

Guiyang municipal urban and rural road passenger transport line to achieve the company management, has high level intensive, large-scale passenger lines in Guiyang. However, the company management does not mean public buses, routes right contracted, affiliated business still occupies a very large proportion, this problem is universal across the country, is particularly serious in Guiyang, Guizhou.

(4)Public transportation in poor and rural passenger transport undertakings operating

City bus routes and rural passenger transport universality reported book losses. City bus routes and rural passenger transport operations benefit poor majority claimed loss in transit companies operating status, urban public transport corporation bus companies and counties engaged in the book are at a loss. Part of rural passenger transport routes operators also are unsustainable or had to stopped state.

\section{Conclusions}

This paper analyzes the situations of integrated development of the urban and rural road passenger transport in Guiyang, Comprehensive analysis of the problems existing in the development and reference the good experience of LiYang and JiaXing Finally, paper proposes measures. This paper provides a theoretical foundation and technical support integrated development of urban and rural road passenger transport for Guiyang, even for GuiZhou province or Country. The research will be helpful in promoting the Equalization of basic public services in urban and rural road passenger 
transport development, to provide rural residents with safe, convenient, economical and efficient service[5].

\section{Acknowledgements}

The research was financially supported by the Projects of the National Natural Science Fund Committee "Research on Urban space based on different scales of heterogeneity effect on urban public transportion” (41471459).

\section{References}

[1] LIU Panlong. Analysis on the work of integrated development of urban and rural passenger transport in Guiyang[R]Guiyang: Transport Commission Of Guiyang.2013.

[2] GU Zhibin, XIANG Wei, GUO Xiucheng, Research on the Strategy of Integrated Development of the Public Transit in Urban and Rural Areas $[\mathrm{J}]$. Journal of Highway and Transportation Research and Development, 2006, 23(5):113-118.

[3] HUANG Li, LI Xuhong, HE Jie. Discussion of Some Problems about the Integration of Urban and Rural Public Transportation [ J ] Planners, 2006(3):76-78.

[4] JIANG Yulin, et al. National Report on Urban Passenger Transport Development,[M]China Communications Press Co.,Ltd. 2011, P96

[5] HAN Biao, WANG Xin, LIU Qiang, et al. Study on the Urban and Rural Integrated Passenger Transport about Adjacent Cities [M] . Shanghai: Shanghai Sanlian Bookstore, 2006. 